\title{
IDENTIFICATION, MOLECULAR CHARACTERIZATION AND EVALUATION OF SOME RUMINAL BACTERIA THAT CATALYZE AND DEGRADE PLANT CELLULOSIC MATERIALS
}

\author{
${ }^{1}$ Ahmed A. Mansour, ${ }^{2}$ T.S. El-Tayeb and ${ }^{3}$ N.E. El-Bordeny \\ ${ }^{1}$ Department of Genetics, Faculty of Agriculture, Ain Shams University, Cairo, Egypt and \\ Department of Medical Biotechology, College of Applied Medical Sciences, University of Taif, (branch Truba), KSA \\ ${ }^{2}$ Department of Agricultural Microbiology, \\ ${ }^{3}$ Department of Animal Production, \\ Faculty of Agriculture, Ain Shams, University, Shoubra El-Kheima, Cairo, Egypt
}

Received 2013-10-05; Revised 2013-10-21; Accepted 2013-12-10

\begin{abstract}
In the last few years there was a growing economic awareness about plant wastes and use it in compost production or in feeding of farm animals, some of these wastes are useless and cause a lot of problems in Egyptian environment. This study was designed to isolate, identify and evaluate some ruminal bacterial isolates to facilitate the in vitro degradation of certain local agro-industrial wastes (rice straw and corn stalks). Two bacterial isolates were isolated from rumen fluid of some Egyptian cattle and identified as Fibrobacter succinogenes and Ruminococcus albus depending on morphological, biochemical identification and molecular characterization using $16 \mathrm{~S}$ rRNA genes. Two degenerate primers were used to detect about $1.6 \mathrm{~kb}$ PCR fragment, a partial sequences (709 and 401) bp were sequenced for $F$. succinogenes and $R$. albus respectively. The highest similarity was detected for both isolates which were $57 \%$ with Streptomyces sp. for $F$. succinogenes and $77 \%$ with Enterobacter sp. for $R$. albus. The two isolates were subjected in-vitro to catalyze and degrade rice straw and corn stalks. After four weeks of fermentation, degradation was measured depending on the bacterial growth and changes in chemical components of the degraded materials. The degradation of corn stalks was highly significant comparing to rice straw which inoculated by $F$. succinogenes or $R$. albus. Analysis of the chemical composition showed a decrease in Organic Matter (OM), Crude Fiber (CF), Neutral Detergent Fiber (NDF), Acid Detergent Fiber (ADF), cellulose and hemicellulose content. The inoculum $7.5 \mathrm{~mL} / 50 \mathrm{~g}$ of Ruminococcus albus is more efficient to degrade rice straw or corn stalks in four weeks fermentation period. Corn stalks are better than rice straw to enhance the cellulolytic bacteria to grow in all treatments.
\end{abstract}

Keywords: Rumen Bacteria, Cellulolytic Bacteria, Fibrobacter Succinogenes, Ruminococcus Albus, 16S rRNA

\section{INTRODUCTION}

The first chamber of ruminant's stomach (rumen) contains a large population of microbes. The rumen microbial ecosystem comprises at least 30 predominant bacterial species at a total concentration of $10^{10}$ to $10^{11} / \mathrm{mL}$ of rumen fluid (Weimer, 2011; McSweeney and Mackie, 2012). Most of these microbes degrade cellulolytic materials. It is well known that cellulose is one of the most abundant biopolymers on earth and is an important structural component of the plant cell wall. Bacterial species of

Corresponding Author: Ahmed A. Mansour, Department of Genetics, Faculty of Agriculture, Ain Shams University, Cairo, Egypt and Department of Medical Biotechology, College of Applied Medical Sciences, University of Taif, (branch Truba), KSA 
the rumen are considered important in determining the extent and rate of feed degradation and utilization for microbial protein production (Crossland et al., 2012). Since the establishment of effective methods to isolate and cultivate ruminal microbiota, a number of cellulolytic rumen bacteria, such as the genera Fibrobacter, Ruminococcus, Clostridium, Lactobacillus and Prevotella, have been isolated (Nikki et al., 2011). In addition to $F$. succinogenes and $R$. flavefaciens, $R$. albus is one of the main cellulolytic bacteria in the rumen (McSweeney and Mackie, 2012). In vitro studies have shown that $R$. albus became predominant over the other two fibrolytic species in co-cultures containing cellulose as well as in the rumen of cows (Wilson, 2011), but is outnumbered by the other rumen cellulolytic species, $R$. flavefaciens and $F$. succinogenes, in the rumen of sheep (McSweeney and Mackie, 2012). Ruminants have developed a unique microbial symbiosis in the rumen to utilize this plant tissue but non fermentable fiber can often be recovered from the faeces (Quiroz-Castaeda and Folch-Mallol, 2011; McSweeney and Mackie, 2012). Therefore, it can be hypothesized that the microbial population in the rumen is limiting and under normal feeding conditions, the fermentation of structural carbohydrates is a slow process (Messana et al., 2012). Therefore, efforts were done to enhance the microbial cellulosic digesting ecosystem. Thoetkiattikul et al. (2013) noticed that, there was an elevation of the fibrolytic bacterial numbers in the rumen by feeding a high-cellulose diet composed of purified wood cellulose. There was a 10-fold increase in the number of cellulolytic bacteria, but no significant increase in the digestion of alfalfa (lucerne) cellulose when it was placed in a nylon bag and suspended in the rumen for $24 \mathrm{~h}$. Koike et al. (2000) reported a seasonal variation in cellulolytic bacterial species in the caecum of Hokkaido native horses: F. succinogenes was predominant in winter and $R$. albus and $R$. flavefaciens were predominant in summer. $F$. succinogenes was the most extensive lignocellulosic degradation in vitro; ferment cellobiose and glucose. If fiber digestibility is to be improved by microbial manipulation, a very significant, issue is whether introduced organisms can multiply and persist at levels in the rumen that are sufficient to improve fiber digestion (Fukuma et al., 2011).
Marked developments have occurred in bacterial identification and classification since the application of molecular technologies to this task. The impetus for major change has resulted from the observation that $16 \mathrm{~S}$ ribosomal DNA (rDNA) sequences can be used as evolutionary chronometers (Shakira et al., 2012). Some regions of the $16 \mathrm{~S}$ rDNA molecule are conserved throughout all bacterial species and can be used to align sequences obtained from different isolates (Yang et al., 2010a). Analysis of rDNA give a basis for describing microbial communities without the limitations imposed by culture based methods and biochemical identification (Petri et al., 2012). Similarities in nucleotide sequences serve to relate microorganisms and can be used to identify uncultured microbes in environmental studies. Recent studies using comparative sequencing of bacterial 16S rDNA clearly indicated that there is a high degree of genetic divergence among rumen isolates previously thought to represent strains of a single species (Yang et al., 2010b; Chaudhary et al., 2012; Petri et al., 2012).

This study is interested in isolation and identification of some cattle ruminal bacteria depending on its $16 \mathrm{~S}$ rDNA genes and can in vitro degrade rice straw and corn stalks.

\section{MATERIALS AND METHODS}

\subsection{Sampling}

Representative samples (at least $500 \mathrm{~g}$ ) of rumen content were collected from cattle, the sample were brought immediately to the laboratory, containing proportions of solid and liquid materials which approximated those in the original was continually gassed with $\mathrm{CO}_{2}$. The samples were then strained through four-layer sterilized cheesecloth. The obtained rumen fluid was then used for isolating of fiberdigesting bacteria. Most probable number calculations were then used to estimate the numbers of total bacterial count and cellulolytic bacterial count in rumen fluid on nutrient broth and cellulose broth medium, respectively (Nikki et al., 2011).

\subsection{Isolation and Identification of Fiber- Digesting Rumen Bacteria}

Sterilized test tubes containing cellulose broth medium supplemented with strips of filter paper were firstly inoculated with a loop of previously prepared 
rumen fluid for culturing of cellulolytic bacteria. The tubes were incubated in an anaerobic incubator (Hirayama Manufacturing Corp., Tokyo, Japan) at $39^{\circ} \mathrm{C}$ for 21 days and scored positive if there was any visual breakdown of the cellulose strips. In order to isolate the cellulolytic bacteria, tubes that were scored positive vortexed for $30 \mathrm{sec}$ and $1 \mathrm{~mL}$ of bacterial culture was serially diluted ten-fold up to $10^{-7}$. Three dilutions $\left(10^{-5}, 10^{-6}\right.$ and $\left.10^{-7}\right)$ were used to inoculate petri dishes containing cellulose agar medium. After incubation for $96 \mathrm{~h}$ at $39^{\circ} \mathrm{C}$, single colonies showing zones of clearance on cellulose agar were picked and inoculated anaerobically at $39^{\circ} \mathrm{C}$ into a broth of cellulose medium with $(0.2 \%)$ glucose. After another $48 \mathrm{~h}$ of incubation, the cultures were examined microscopically to check the purity, morphology and gram staining characteristics. The colonies were picked up, purified then maintained on nutrient agar at $4^{\circ} \mathrm{C}$ (Nikki et al., 2011). The biochemical identification of the isolates were carried out and reconfirmed in the Micro Analytical Centre, Cairo University, Giza, Egypt.

\subsection{DNA Extraction and PCR}

DNA was extracted from the isolated bacteria by using AxyPrep Bacterial Genomic DNA Miniprep Kit (Axygen Biosciences USA). The isolated DNA was applied for PCR test. Two PCR Primers [Forward (AGA GTT TSA TCC TGG CTC AG)] and [Reverse (ACG GMT ACC TTG TTA CGA CTT)] were used in this study to amplify a partial segment of bacterial ribosomal DNA. PCR amplification was performed by using a $50 \mu \mathrm{L}$ (total volume) mixture containing 1.25 U of Taq DNA polymerase (Amplitaq Gold, PerkinElmer), 15 mM Tris-HCl (pH 8.0), $50 \mathrm{mM} \mathrm{KCl,} 2.5$ $\mathrm{mM} \mathrm{MgCl}_{2}$, each deoxynucleoside triphosphate at a concentration of $200 \mu \mathrm{M}, 25 \mathrm{pmol}$ of each primer and 10-50 ng of the extracted DNA. The thermal cycle involved 5-min pre-heating at $94^{\circ} \mathrm{C}$ before 30 cycles consisting of $1 \mathrm{~min}$ at $94^{\circ} \mathrm{C}, 1 \mathrm{~min}$ at 50 and $2 \mathrm{~min}$ at $72^{\circ} \mathrm{C}$. Finally, a 10 -min extension at $72^{\circ} \mathrm{C}$ was performed. Amplification of PCR products of the proper size was confirmed by electrophoresis through $1.5 \%(w / v)$ agarose gel (Sigma) in TBE buffer, stained with ethidium bromide (Shakira et al., 2012). The PCR product of each sample was subjected to electrophoresis on $1.2 \mathrm{~g} \%$ agarose gel. A $1.6 \mathrm{~kb}$ PCR fragment was observed and eluted from the gel using QIAquick Gel Extraction Kit (250) (cat. no. 28706 QIAgen). The forward primer was used in sequencing of the eluted PCR products; the sequencing process was done in Sigma (Germany) by the automated sequencer.

\subsection{Nucleotide Sequence Analysis}

Database searches with determined sequences were conducted by using the BLASTN programs in the GenBank on web site http://blast.ncbi.nlm.nih.gov/Blast.cgi. The sequences were aligned online by using BLASTN, version 2.2.21+ (on the web site http://blast.ncbi.nlm.nih.gov/Blast.cgi?PROGRAM=bla stn\&PAGE_TYPE=BlastSearch\&LINK_LOC=blastho me) and the alignments were refined by visual inspection. The nucleotide sequences reported in this study have been registered in the EMBL database nucleotide under accession nos. (GQ505949) for $F$. succinogenes and (GQ505950) for R. albus.

\subsection{Preparation of Pre-Bacterial Cultures}

Three litters of Luria Broth (LB) medium were divided equally into 3 conical flasks (2L), sterilized, then inoculated separately with one of each of bacterial strains and rumen fluid, incubated anaerobically at $39^{\circ} \mathrm{C}$ for $48 \mathrm{~h}$ to obtain high density growth ( $1 \mathrm{~mL}$ contained $2-3 \times 10^{7}$ viable cells $)$ (Nikki et al., 2011).

\subsection{Cellulosic Materials Bio-Treatment}

Rice straw and corn stalks were collected from farms of rice and corn in El-Beheira governorate (Delta of the Nile north of Cairo, Egypt lat. 30.921076375384878, long. 30.2728271484375). The chopped Rice straw $(3-5 \mathrm{~cm})$ and the crushed corn stalks were weighted $(50 \mathrm{~g})$, packed and autoclaved at $121^{\circ} \mathrm{C}$ for $30 \mathrm{~min}$, then stored at room temperature until use. The Molasses Urea Medium (MUM) containing $(5 \%)$ crude sugar cane molasses (about $50 \%$ w/w total sugars) (Sugar Refinery Factory at ElHawamdia, Giza, Egypt) and (3\%) urea (46\% N w/w) (Abo Qir Fertilizers Company, Alexandria, Egypt) was prepared for all fermentation treatments. $50 \mathrm{ml}$ of MUM was mixed with (zero, 2.5, 5, 7.5 and $10 \mathrm{~mL}$ ) of $F$. succinogenes or $R$. albus or rumen fluid (positive 
control) cultures and the final volume was adjusted to $80 \mathrm{~mL}$ by sterilized water, then added to $50 \mathrm{~g}$ of the rice straw or corn stalks in sterilized polyethylene bags. The negative control was bags supplied with 80 $\mathrm{mL}$ of sterilized water. All bags were tightly closed and incubated at $39^{\circ} \mathrm{C}$ for 6 weeks. Representative samples were taken after zero, 2, 4 and 6 weeks of inoculation. Bacteria were counted on standard cellulose agar plates (Anand et al., 2010). The contents of all bags were oven dried at $65^{\circ} \mathrm{C}$ for $24 \mathrm{~h}$.

\subsection{Analytical Methods}

Dried samples were ground through a Wiley Mill fitted with a $1.5 \mathrm{~mm}$ screen. The chemical composition of the cellulosic materials were carried out using the standard laboratory analytical procedures for biomass analysis provided by the National Renewable Energy Laboratory (NREL, USA) and methods developed by the Association of Official Analytical Chemistry for biomass analysis. Dry matter analyzing methods (DM, method 930.15), crude protein (CP, method 954.01), crude fiber (CF, method 962.09), ether extract (EE, method 920.39) and ash (method 942.05) (AOAC, 1995). Neutral Detergent Fiber (NDF) was assayed with a heat stable amylase and expressed inclusive of residual ash, Acid Detergent Fiber (ADF) expressed inclusive of residual ash and Acid Detergent Lignin (ADL) were determined according to Van Soest et al. (1991). Cellulose and hemicellulose values were calculated according to the results of analysis as: Cellulose $=$ ADF-ADL and Hemicellulose $=$ NDFADF. The volatile or organic matter portion of the dried samples was determined by burning at $550^{\circ} \mathrm{C}$ in a muffle furnace (Blue $\mathrm{M}$ Electric Company, Blue Island, USA) for $4 \mathrm{~h}$. Organic Matter (OM) was calculated as: 100-ash \%, while carbon content (\%) was determined by dividing the volatile fraction by 1.83. Carbon content $(\%)=(100$-ash $\%) / 1.83$ (Barrington et al., 2002). The obtained data were statistically analyzed using the general linear model procedure described in SAS statistical software User's Guide as the following model:

$$
\mathrm{Y}_{\mathrm{ijk}}=\mu+\mathrm{M}_{\mathrm{i}}+\mathrm{L}_{\mathrm{j}}+\mathrm{P}_{\mathrm{k}}+\mathrm{E}_{\mathrm{ijk}}
$$

Where:

$\mathrm{Y}_{\mathrm{ijk}}=$ Observed trait $\mu \quad=$ The overall mean

$M_{i}=$ The effect of $i^{\text {th }}$ inculants

$\mathrm{L}_{\mathrm{j}}=$ The effect of $\mathrm{j}^{\text {th }}$ level of inoculants

$\mathrm{P}_{\mathrm{ij}}=$ the effect of $\mathrm{k}^{\text {th }}$ period of incubation and $\mathrm{E}_{\mathrm{ijk}}=$ Random error.

Mean differences between experimental groups were tested by Duncan's multiple range test (Duncan, 1955).

\section{RESULTS}

\subsection{Fiber-Degrading Bacteria}

The estimated total number of viable bacteria in ruminal fluid was $5.0 \times 10^{9} \mathrm{cfu} \mathrm{ML}^{-1}$ while the number of cellulolytic bacteria was $3.2 \times 10^{7} \mathrm{cfu} \mathrm{mL}^{-1}$. Two bacterial isolates showed the highest cellulose clearance zones on cellulose agar medium. These isolates were typically Gram-negative short rods or Gram-positive cocci. The first isolate was identified as Fibrobacter succinogenes. It was Gram-negative none motile rods but can become coccoid or oval on culture. The other one was Gram-positive cocci and identified as Ruminococcus albus, produced a yellow pigment when grown on cellulose.

\subsection{Bacterial Identification Characterization at Molecular Level}

and

Total DNA was extracted from the two bacterial isolates ( $F$. succinogenes and $R$. albus) and subjected to PCR conditions with degenerated primers of $16 \mathrm{~S}$ rDNA. About $1.6 \mathrm{~Kb}$ PCR products was performed and sequenced by Sigma Company (Germany) using the forward primer and the sequenced parts were 709 and $401 \mathrm{bp}$ for $F$. succinogenes and $R$. albus respectively. Each sequence was aligned with different bacterial DNA sequences stored in NCBI GenBank database. The highest Query coverage of $F$. succinogenes sequence was $57 \%$ with Streptomyces sp., while it was $77 \%$ with Enterobacter sp. in the case of $R$. albus.

\subsection{Cellulolytic Bacterial Growth on Rice Straw and Corn Stalks}

The isolated bacterial strains ( $F$. succinogenes and $R$. albus) and the cattle rumen fluid were evaluated in the polyethylene plastic bags for their degradation 
efficiencies on either rice straw or corn stalks. The degradation effect was assessed by monitoring the bacterial growth and changes in chemical composition of rice straw and corn stalks. Data in Table 1 and Fig. 1 showed significant increases of bacterial counts on fermented materials due to almost all inoculation treatments. However, the counts were dropped or remained constant in the last two weeks of fermentation. The inoculation with rumen fluid (positive control) gave less bacterial counts on either rice straw or corn stalks comparing with single inoculations of each of $F$. succinogenes or $R$. albus (Table 1 and Fig. 1). The inoculations with (7.5 $\mathrm{mL} / 50 \mathrm{~g}$ ) of either rice straw or corn stalks (in all fermentation periods) achieved significantly higher or sometimes close counts of cellulolytic bacteria comparing with those in case of inoculation with (10 $\mathrm{mL} / 50 \mathrm{~g})$. After 4 weeks of fermentation, the 7.5 $\mathrm{mL} / 50 \mathrm{~g}$ inoculation exhibited the highest growth of $R$. albus or $F$. succinogenes on rice straw with rates of $6.5 \times 10^{6} \mathrm{cfu} / \mathrm{g}$ (1.1 fold) and $6.1 \times 106 \mathrm{cfu} / \mathrm{g}$ (1.05 fold) respectively and gave a growth on corn stalks with rates of $7.9 \times 10^{6} \mathrm{cfu} / \mathrm{g}(1.5$ fold $)$ and $6.7 \times 10^{6} \mathrm{cfu} / \mathrm{g}(1.3$ fold) respectively, comparing with the positive control.

\subsection{Degradation Activity of Cellulolytic Bacteria on Rice Straw and Corn Stalks}

Cellulolytic bacteria ( $F$. succinogenes and R. albus) showed higher $(\mathrm{p}<0.05)$ degradation activity expressed in cell wall constitutes (NDF, ADF, cellulose and hemicelluloses) compared with rumen fluid at different incubation periods (Table 2) and (Fig. 2) and different inoculation levels (Fig. 3) for both roughage materials (rice straw and corn stalks). The data in Table 2 showed that, no difference between $F$. succinogenes, $R$. albus or rumen fluid which decreased the OM, CF, NFE, NDF, ADF, cellulose and hemicellulose content compared to the untreated materials. Gradual increase in degradation activity were recorded for $R$. albus, $F$. succinogenes and rumen fluid parallel to the increase in incubation time up to 4 weeks then tend to constant (Fig. 2).

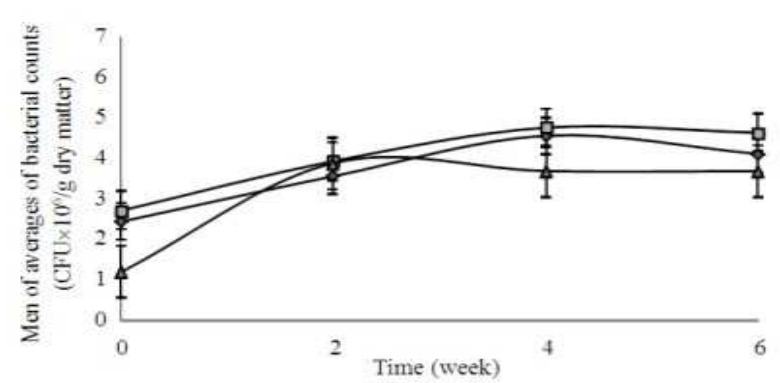

(A)

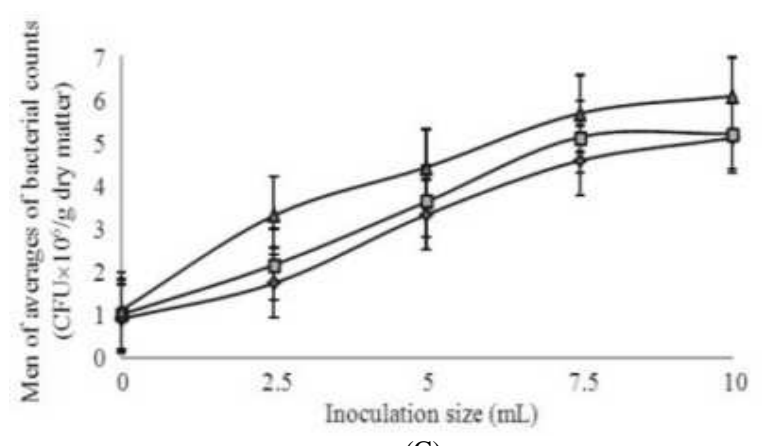

(C)

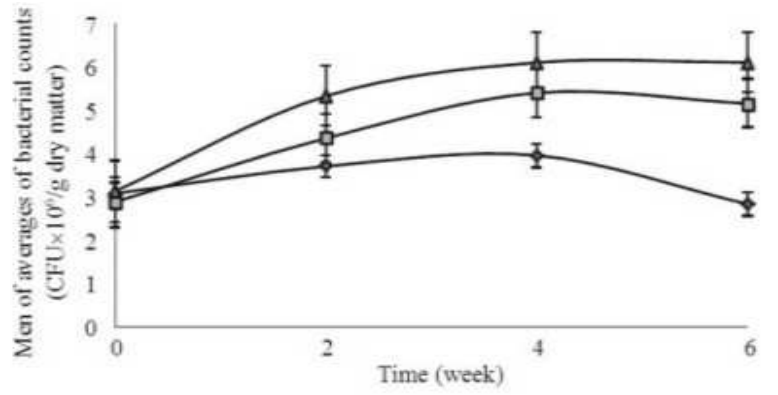

(B)

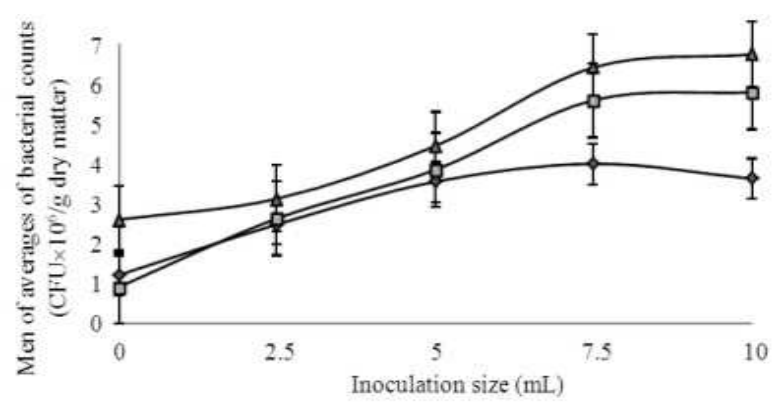

(D)

Fig. 1. Growth of total rumen bacteria $\diamond, F$. succinogenes $\square$ and R. albus $\Delta$ on rice straw (A) and corn stalks (B) at different incubation time, while (C) and (D) on rice straw and corn stalks at different inoculation sizes respectively 
Ahmed A. Mansour et al. / American Journal of Applied Sciences 11 (1): 127-136, 2014
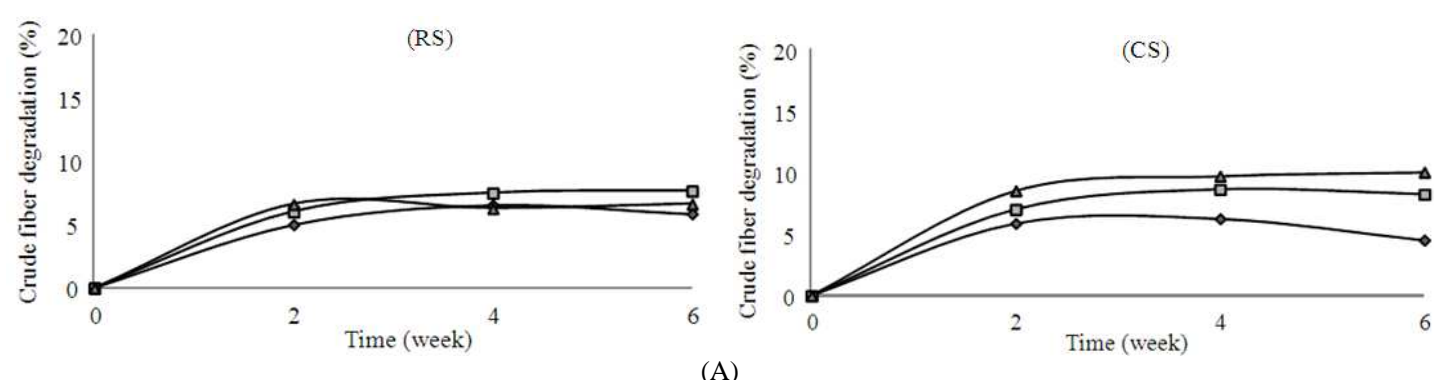

(A)
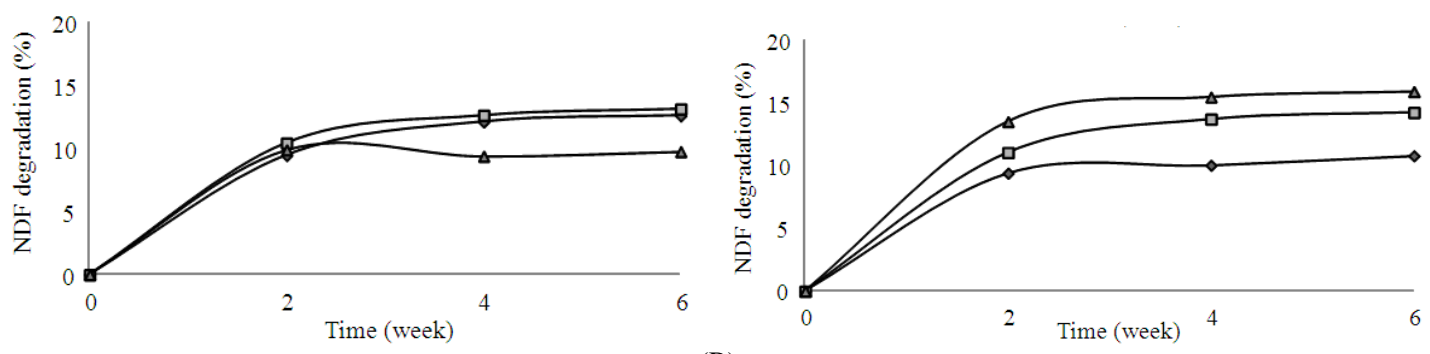

(B)
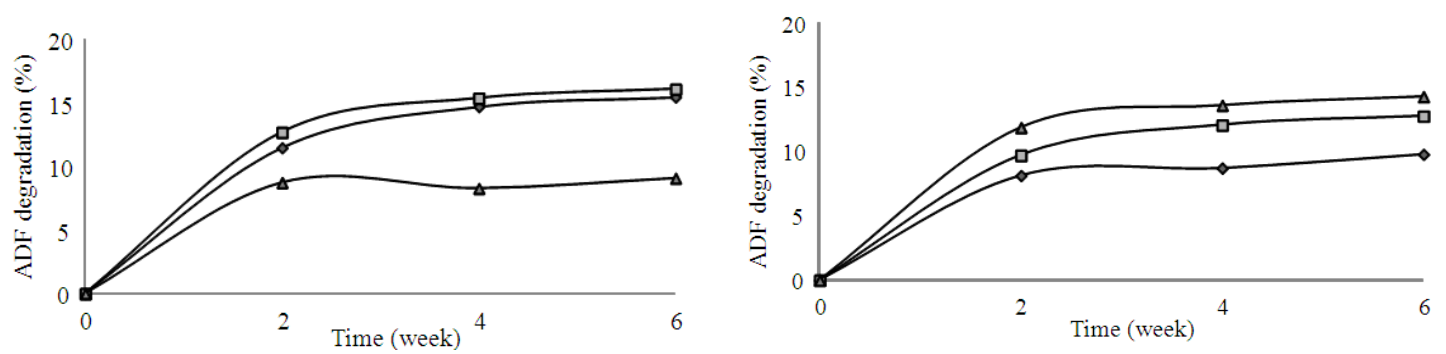

(C)
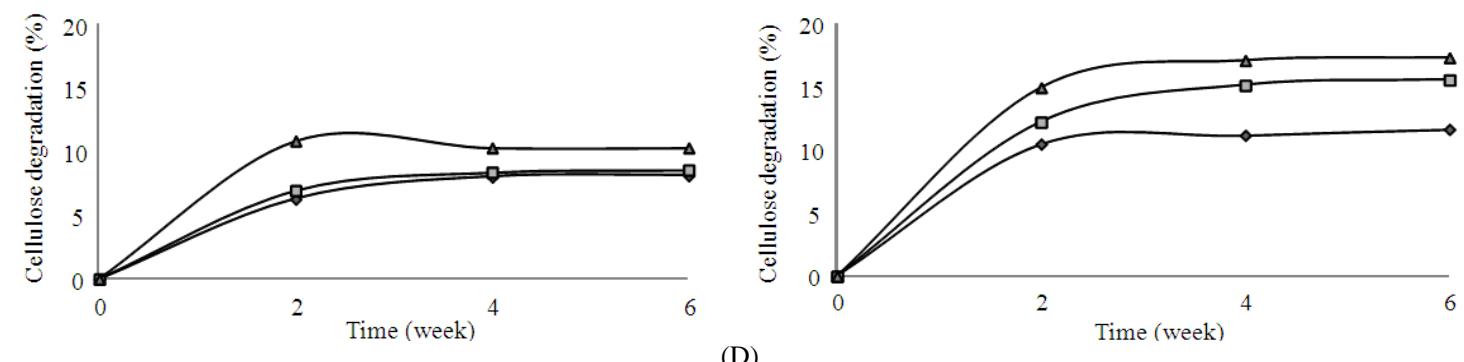

(D)
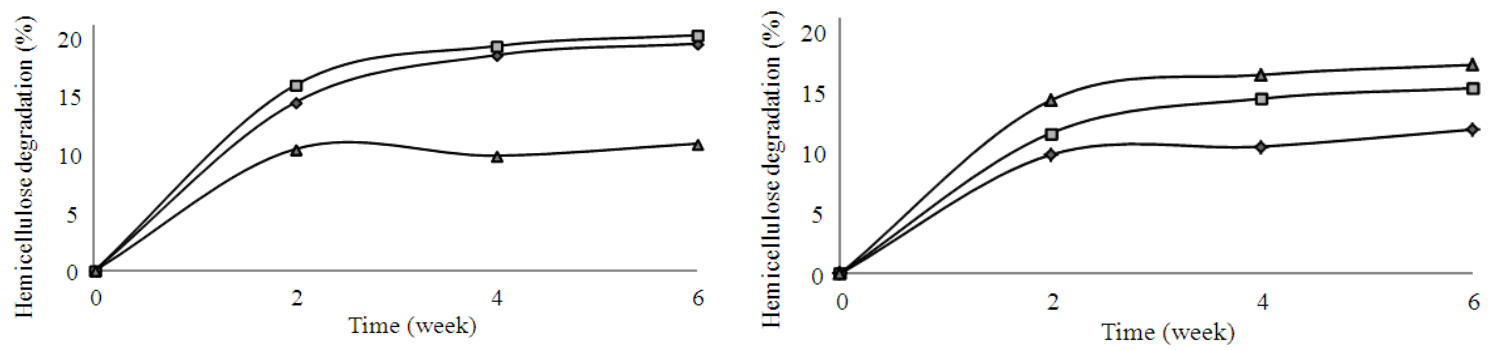

(E)

Fig. 2. Comparison of in vitro degradation of Rice Straw (RS) or Corn Stalks (CS) at different incubation time by rumen fluid $\diamond F$. succinogenes $\square$ or $R$. albus $\triangle(\mathrm{A})=$ crude fiber $(\mathrm{B})=\mathrm{NDF}(\mathrm{C})=\mathrm{ADF}(\mathrm{D})=$ cellulose and $(\mathrm{E})=$ Hemicellulose degradation 
Ahmed A. Mansour et al. / American Journal of Applied Sciences 11 (1): 127-136, 2014
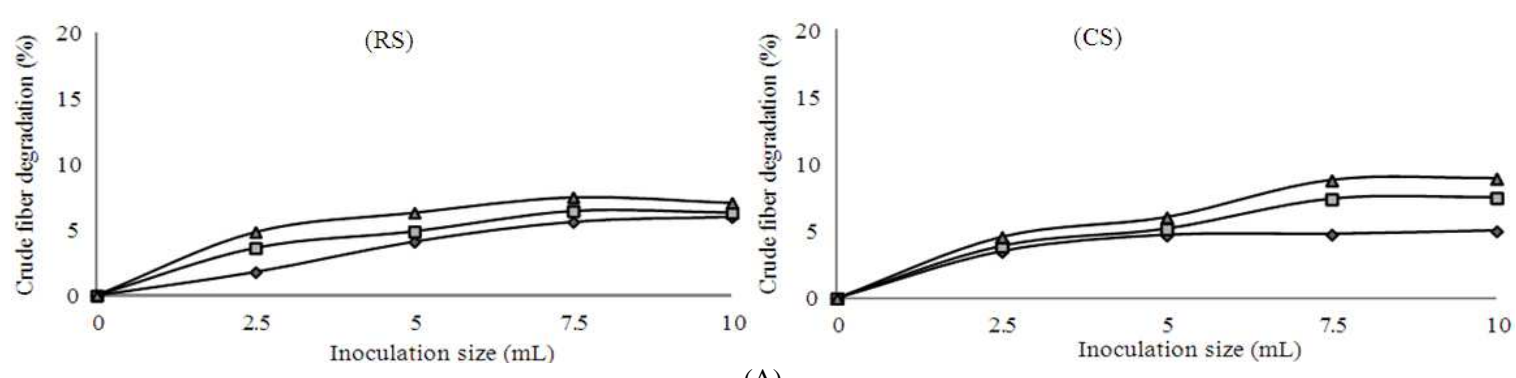

(A)
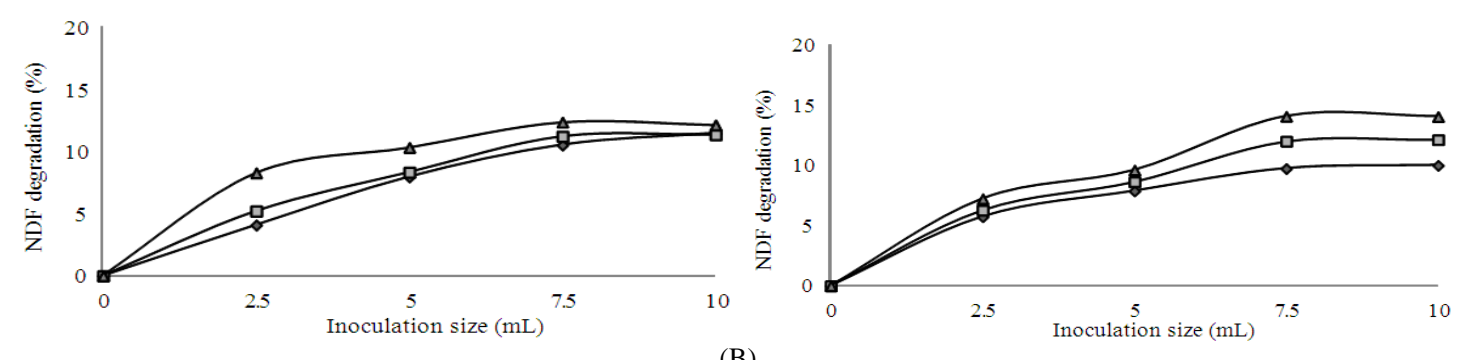

(B)
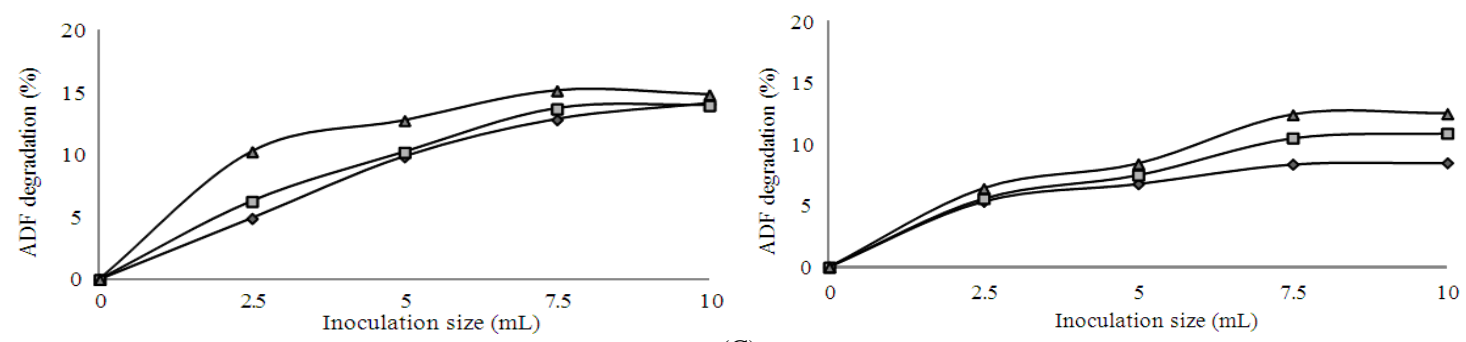

(C)
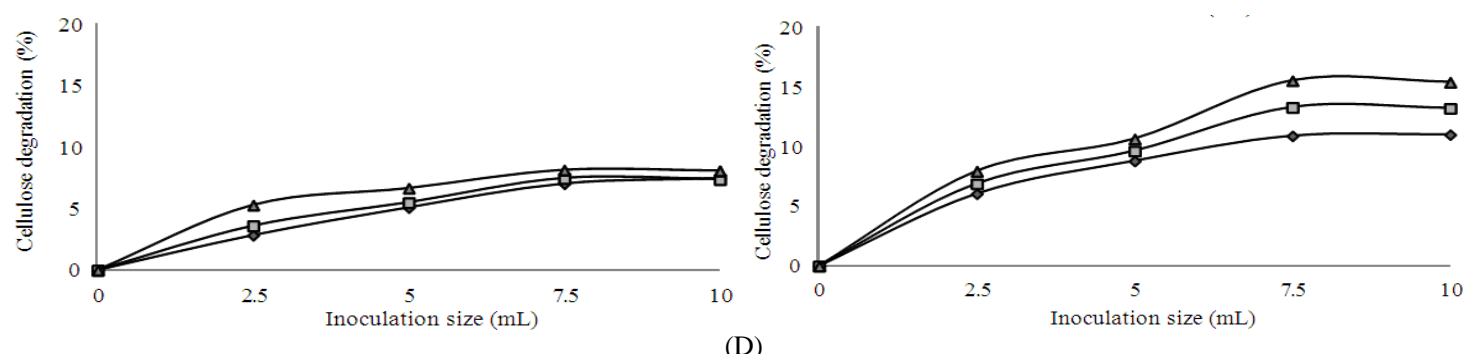

(D)
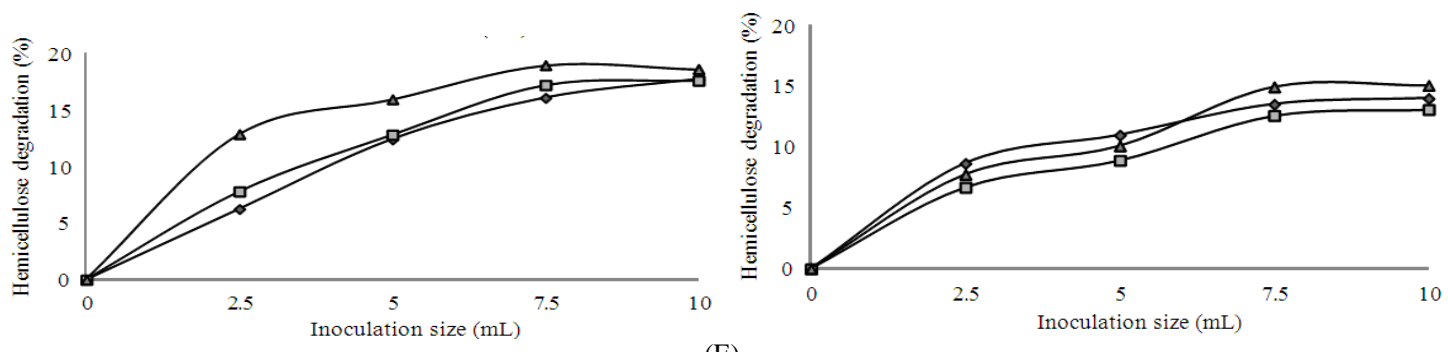

(E)

Fig. 3. Comparison of in vitro degradation of Rice Straw (RS) or Corn Stalks (CS) at different inoculation volumes by rumen fluid $\diamond F$. succinogenes $\square$ or $R$. albus $\Delta(\mathrm{A})=$ crude fiber, $(\mathrm{B})=\mathrm{NDF},(\mathrm{C})=\mathrm{ADF}$, (D) cellulose and $(\mathrm{E})=$ Hemicellulose degradation 
Ahmed A. Mansour et al. / American Journal of Applied Sciences 11 (1): 127-136, 2014

Table 1. Average cellulolytic bacteria counts ( $\left.\mathrm{cfu} \times 10^{6} / 1 \mathrm{gm}\right)$ incubated with rice straw or corn stalks after zero, 2 , 4 and 6 weeks of inoculation at $39^{\circ} \mathrm{C}$ with different enhancing fiber-degrading treatments

\begin{tabular}{|c|c|c|c|c|c|c|c|c|c|c|c|}
\hline \multirow[b]{2}{*}{ Treatments } & \multirow{2}{*}{$\begin{array}{l}\text { Time after } \\
\text { inoculation } \\
\text { (weeks) }\end{array}$} & \multicolumn{5}{|c|}{ Volume of each treatment added to $50 \mathrm{~g}$ rice straw } & \multicolumn{5}{|c|}{ Volume of each treatment added to $50 \mathrm{~g}$ corn stalks } \\
\hline & & $2.5 \mathrm{~mL}$ & $5.0 \mathrm{~mL}$ & $7.5 \mathrm{~mL}$ & $10 \mathrm{~mL}$ & Mean & $2.5 \mathrm{~mL}$ & $5.0 \mathrm{~mL}$ & $7.5 \mathrm{~mL}$ & $10 \mathrm{~mL}$ & Mean \\
\hline \multirow[t]{4}{*}{ Rumen fluid } & 0 & 0.9000 & 1.7000 & 3.000 & 4.2000 & $3.7375^{\mathrm{c}}$ & 1.2000 & 2.2000 & 4.0000 & 5.0000 & $3.4125^{\mathrm{c}}$ \\
\hline & 2 & 1.7000 & 3.2000 & 4.200 & 5.2000 & & 2.4000 & 3.6000 & 4.7000 & 4.2000 & \\
\hline & 4 & 2.2000 & 4.3000 & 5.800 & 6.0000 & & 3.2000 & 4.3000 & 5.2000 & 3.2000 & \\
\hline & 6 & 2.1000 & 4.1000 & 5.300 & 5.0000 & & 3.1000 & 4.1000 & 2.1000 & 2.1000 & \\
\hline Fibrobacter & 0 & 1.0000 & 2.1000 & 3.500 & 4.3000 & & 0.9000 & 2.4000 & 3.8000 & 4.5000 & \\
\hline \multirow[t]{3}{*}{ succinogenes } & 2 & 2.3000 & 3.4000 & 4.600 & 5.5000 & & 2.8000 & 3.8000 & 5.3000 & 5.6000 & \\
\hline & 4 & 2.7000 & 4.5000 & 6.100 & 5.8000 & $4.0458^{\mathrm{b}}$ & 3.5000 & 4.8000 & 6.7000 & 6.7000 & $4.4687^{\mathrm{b}}$ \\
\hline & 6 & 2.6000 & 4.5000 & 6.300 & 5.2000 & & 3.3000 & 4.4000 & 6.6000 & 6.4000 & \\
\hline Ruminococcus & 0 & 1.1000 & 2.5000 & 4.100 & 5.0000 & & 1.2000 & 2.6000 & 4.0000 & 4.8000 & \\
\hline \multirow[t]{3}{*}{ Albus } & 2 & 3.1000 & 4.5000 & 5.600 & 6.5000 & & 3.9000 & 4.5000 & 6.3000 & 6.7000 & \\
\hline & 4 & 4.7000 & 5.5000 & 6.500 & 6.3000 & $4.8234^{\mathrm{a}}$ & 3.7000 & 5.2000 & 7.9000 & 7.7000 & $5.0532^{\mathrm{a}}$ \\
\hline & 6 & 4.3000 & 5.2000 & 6.500 & 6.5000 & & 3.7000 & 5.5000 & 7.5000 & 7.8000 & \\
\hline Mean & & $2.4944^{\mathrm{c}}$ & $3.7917^{b}$ & $5.125^{\mathrm{a}}$ & $5.4143^{\mathrm{a}}$ & & $2.7333^{\mathrm{c}}$ & $3.9500^{\mathrm{b}}$ & $5.2583^{\mathrm{a}}$ & $5.3114^{\mathrm{a}}$ & \\
\hline
\end{tabular}

The values are mean of three replicates. Standard deviation was within $10 \%$. Values followed by the same (a, b, or c) letter do not significantly differ from each other, according to Duncan's at 5\% level

Table 2. Chemical analysis (\%) and cell wall composition (\%) of treated rice straw and corn stalks as affected by ruminal bacteria and rumen fluid inoculations at the level of $7.5 \mathrm{~mL}$ after 4 weeks of incubation period at $39^{\circ} \mathrm{C}$

\begin{tabular}{|c|c|c|c|c|c|c|c|c|}
\hline \multirow{2}{*}{$\begin{array}{l}\text { Chemical } \\
\text { analysis }\end{array}$} & \multicolumn{4}{|c|}{ Rice straw } & \multicolumn{4}{|c|}{ Corn stalks } \\
\hline & Control & Rumen fluid & F. succinogenes & R. albus & Control & Rumen fluid & F. succinogenes & R. albus \\
\hline $\mathrm{DM}$ & 93.26 & 94.78 & 93.26 & 93.48 & 92.84 & 94.47 & 92.73 & 93.10 \\
\hline $\mathrm{OM}$ & 85.78 & 81.47 & 81.36 & 80.54 & 89.11 & 86.65 & 86.22 & 85.93 \\
\hline $\mathrm{CP}$ & 4.08 & 8.62 & 8.69 & 8.62 & 4.03 & 9.65 & 9.80 & 9.93 \\
\hline $\mathrm{CF}$ & 38.88 & 34.36 & 35.13 & 34.12 & 37.01 & 34.21 & 34.02 & 32.46 \\
\hline $\mathrm{EE}$ & 1.21 & 1.29 & 1.29 & 1.30 & 1.31 & 1.33 & 1.40 & 1.46 \\
\hline Ash & 14.22 & 18.53 & 18.64 & 19.46 & 10.89 & 13.35 & 13.78 & 14.07 \\
\hline NDF & 80.40 & 65.11 & 66.12 & 63.58 & 81.36 & 67.15 & 68.11 & 65.07 \\
\hline $\mathrm{ADF}$ & 48.52 & 36.21 & 38.90 & 36.09 & 37.66 & 32.25 & 31.53 & 31.00 \\
\hline ADL & 10.30 & 10.01 & 9.82 & 9.65 & 7.20 & 6.22 & 6.02 & 5.90 \\
\hline Cellulose & 38.22 & 26.20 & 29.08 & 26.44 & 30.46 & 26.03 & 25.51 & 25.10 \\
\hline Hemicellulose & 31.88 & 28.90 & 27.22 & 27.49 & 43.70 & 34.90 & 36.58 & 34.07 \\
\hline$\% \mathrm{C}$ & 46.87 & 44.52 & 44.46 & 44.01 & 48.69 & 47.35 & 47.11 & 46.96 \\
\hline$\% \mathrm{~N}$ & 0.65 & 1.38 & 1.39 & 1.38 & 0.64 & 1.54 & 1.57 & 1.59 \\
\hline $\mathrm{C}: \mathrm{N}$ ratio & 71.81 & 32.28 & 31.98 & 31.91 & 75.52 & 30.67 & 30.05 & 29.55 \\
\hline
\end{tabular}

The values are mean of three replicates. Standard deviation was within 10\%. Control treatment $=$ Raw materials without bacterial inoculation. DM $=$ Dry matter, $\mathrm{OM}=$ Organic matter, $\mathrm{CP}=$ Crude protein, $\mathrm{CF}=$ Crude fiber, $\mathrm{EE}=$ Ether extract, $\mathrm{NDF}=\mathrm{Neutral}$ detergent fiber, $\mathrm{ADF}=\mathrm{Acid}$ detergent fiber and ADL = Acid detergent lignin

Also, degradation activity increased gradually by both cellulolytic bacteria and rumen fluid paralleled to increasing inoculation size up to $7.5 \mathrm{~mL}$ then tend to be constant (Fig. 3).

\section{DISCUSSION}

By comparing between our isolates and bacteria which were identified at molecular level and registered in EMBL database, similarity alignment did not exceed than $77 \%$, for that, we used the traditional microbial identification methods (morphological and biochemical tests) to identify our isolates and we registered the sequenced 16S rDNA sequences as a novel sequences which can be used in the future to identify the $F$. succinogenes and R. albus at molecular level.

The natural rumen fluid contains a balanced number of microorganisms including bacteria that may catalyze nutrients in a harmony of cooperation while the number of bacterial cells is elevated when exists alone (in-vitro) in a suitable media without any competition with other bacterial species. In a related study, Matulova et al. (2005) grew $F$. succinogenes for up to 4 days with 100 $\mathrm{mg}$ of wheat straw by solid state fermentation. About 50 $\mathrm{mg}$ of straw was degraded with a relative increase in microbial growth. In another comparative study, 
Matulova et al. (2008) found R. albus 20 appeared to be less efficient than $F$. succinogenes $\mathrm{S} 85$ for the degradation of wheat straw in 4 days solid-state fermentation experiment. Microbial growth reached a maximum between 24 and $48 \mathrm{~h}$ and then remained fairly constant. By comparing elevation of the cellulose and hemicelluloses degradation possesses occurred by inoculation with $F$. succinogenes, $R$. albus or the rumen fluid, each strain was highly degraded the plant materials than the rumen fluid and this may be attributed to: (1) $F$. succinogenes or $R$. albus were supportive to fiber degradation, while the rumen fluid contained many species not involved in fiber degradation associated with fiber degrading species. The rumen ecosystem comprises a diverse population of no cellulolytic activity obligatory anaerobic bacteria, fungi and protozoa (Otajevwo, 2011). (2) F. succinogenes or $R$. albus secreted cell wall degrading enzymes (e.g., cellulases, xylanases, âglucanases and pectinases) (Hyun-Sik et al., 2007; Abd El-Galil and Abou-Elenin, 2011). Abd El-Galil and Abou-Elenin (2011) found that rice straw treated with $R$. albus and Clostridium cellulovorans recorded lower CF, NDF, ADF, cellulose and hemicellulose than untreated rice straw. Also the inoculation of rice straw, bagasse and corn stalks with Cellulomonas cellulase, Acetobacter xylinum, Thermonospora fusca, Ruminococcus albus and Bacillus sp. for two months led to degrade the fiber contents and cell wall constitutes and attributed these decrease in $\mathrm{CF}, \mathrm{NDF}$, ADF, cellulose and hemicelluloses for treated material to cellulase enzymes secreted by cellulolytic bacteria.

Bacteria in rumen fluid may have a common system of cellulolytic enzymes and utilize the available carbohydrates (soluble carbohydrate, crude fiber and its fractions) as a source of carbon to produce $\mathrm{CO}_{2}$ and energy. It uses the generated energy and nitrogen sources to grow and consequently decreased the OM content and increased ash content in treated materials. Considering CP content, it is clear that treated materials had higher $\mathrm{CP}$ content compared to untreated. The higher $\mathrm{CP}$ content recorded for treated materials could partly due to: (1) the reduction of organic matter contents as carbohydrates. (2) Trapping of excess ammonia in the biological medium and its subsequent conversion to microbial protein (Gupta et al., 1988). (3) Nitrogen content of added urea, about $3 \%$ of the medium (Abd ElGalil and Abou-Elenin, 2011). Also the treatment with fungus of roughage materials resulted in an increase in $\mathrm{CP}$ content in these materials. In our future research, we will try to isolate some bacteria from camel's rumen fluid and evaluate its ability to degrade different wastes of Egyptian crops.

\section{CONCLUSION}

Using of PCR technique to detect $16 \mathrm{~S}$ rDNA and sequencing of the resulted products can be used as specific markers for the identified bacteria. Two bacteria (Fibrobacter succinogenes and Ruminococcus albus) were isolated from rumen fluid of some Egyptian cattle and molecularly characterized depending in 16S rRNA genes. $1.6 \mathrm{~kb}$ PCR fragment was produced for each isolate and a partial sequences (709 and 401) bp were sequenced for $F$. succinogenes and $R$. albus respectively.

The degradation of corn stalks was highly significant comparing to rice straw which inoculated by $F$. succinogenes or R. albus. The Organic Matter (OM), Crude Fiber (CF), Neutral Detergent Fiber (NDF), Acid Detergent Fiber (ADF), cellulose and hemicellulose content were decreased in both of rice straw and corn stalks after in-vitro treatments for four weeks with each isolates. The inoculum $7.5 \mathrm{~mL} / 50 \mathrm{~g}$ of Ruminococcus albus is more efficient to degrade rice straw or corn stalks in four weeks fermentation period. Corn stalks are better than rice straw to enhance the cellulolytic bacteria to grow in all treatments.

In general the main effect of cellulolytic bacterial growth on celluloytic materials was increasing $\mathrm{CP}$ and ash contents and decreasing OM, CF, NDF, ADF, cellulose and hemicellulose.

\section{REFERENCES}

Abd El-Galil, E.R. and E.I.M. Abou-Elenin, 2011. Role of bacterial treatments for upgrading nutritive value of bean straw and native goats performance. J. Am. Sci., 7: 502-510.

Anand, A.A.P., S.J. Vennison, S.G. Sankar, P.D.I. Gilwax and P.T. Vasan et al., 2010. Isolation and characterization of bacteria from the gut of Bombyxmori that degrade cellulose, xylan, pectin and starch and their impact on digestion. J. Insect Sci., 10: 1-20. DOI: 10.1673/031.010.10701

AOAC, 1995. Official Methods of Analysis of AOAC. 12th Edn., Association of Official Agricultural Chemists, Washington, D.C.

Barrington, S., D. Choiniere, M. Trigui and W. Knight, 2002. Effect of carbon source on compost nitrogen and carbon losses. Bioresour. Technol., 83: 189-194. DOI: 10.1016/S0960-8524(01)00229-2 
Chaudhary, P.P., S.K. Sirohi and J. Saxena, 2012. Diversity analysis of methanogens in rumen of Bubalus bubalis by $16 \mathrm{~S}$ riboprinting and sequence analysis. Gene, 493 : 13-17. DOI: 10.1016/j.gene.2011.11.041

Crossland, M.R., T. Haramura, A.A. Salim, R.J. Capon and R. Shine, 2012. Exploiting intraspecific competitive mechanisms to control invasive cane toads (Rhinella marina). Proc. R. Soc. B. 279: 34363442. DOI: $10.1098 / \mathrm{rspb} .2012 .0821$

Duncan, D.B., 1955. Multiple range and multiple F test. Biometrics, 11: 1-42. DOI: 10.2307/3001478

Fukuma, Y., L. Wang, H. Idzuchi, S. Takahashi and S. Maekawa et al., 2011. Giant enhancement of spin accumulation and long-distance spin precession in metallic lateral spin valves. Nature Mater., 10: 527531. DOI: $10.1038 /$ nmat3046

Gupta, B.N., S.N. Rai, T.K. Walli and K. Singh, 1988. Evaluation of fungal treated rice straw at different fermentation periods in relation to dry matter intake and nutrient utilization in goats. Ind. J. Anim. Nutr., 5: 273-279.

Hyun-Sik, J., M. Qi, J. Gong, E.E. Egbosimba and C.W. Forsberg, 2007. Outer membrane proteins of Fibrobacter succinogenes with potential roles in adhesion to cellulose and in cellulose digestion. J. Bacteriol., 189: 6806-6815. DOI: 10.1128/JB.00560-07

Koike, S., Y. Shigu, H. Inaba, M. Kawai and Y. Kobayashi et al., 2000. Faecal bacteria in Hokkaido native horses as characterized by microscopic enumeration and competitive polymerase chain reaction assays. J. Equine Sci., 11: 45-50. DOI: 10.1294/jes.11.45

Matulova, M., R. Nouaille, P. Capek, M. Pean and A.M. Delort et al., 2008. NMR study of cellulose and wheat straw degradation by Ruminococcus albus 20 . FEBS J., 275: 3503-3511. DOI: 10.1111/j.17424658.2008.06497.x

Matulova, M., R. Nouaille, P. Capek, M. Péan and M. Forano et al., 2005. Degradation of wheat straw by fibrobacter succinogenes s85: A liquid-and solidstate nuclear magnetic resonance study. Appl. Environ. Microbiol., 71: 1247-1253. DOI: 10.1128/AEM.71.3.1247-1253.2005

McSweeney C. and R. Mackie, 2012. Micro-Organisms and ruminant digestion: State of knowledge, trends and future prospects. PPLD.

Messana, J.D., T.B. Telma, P.B. Arcuri, A.F. Ribeiro and G. Fiorentini et al., 2012. Effects of different lipid levels on protozoa population, microbial protein synthesis and rumen degradability in cattle. Acta Sci. Anim. Sci., 34: 279-285. DOI: 10.4025/actascianimsci.v34i3.12729
Nikki, K., G. Henderson, J. Jeyanathan, S. Kittelmann and P.H. Janssen, 2011. Isolation of previously uncultured rumen bacteria by dilution to extinction using a new liquid culture medium. J. Microbial. Meth., 84: 52-60. DOI: 10.1016/j.mimet.2010.10.011

Otajevwo, F.D., 2011. Cultural conditions necessary for optimal cellulase yield by cellulolytic bacterial organisms as they relate to residual sugars released in broth medium. Modern Applied Sci., 5: 141-151. DOI:10.5539/mas.v5n3p141

Petri, R.M., R.J. Forster, W. Yang, J.J. Mc Kinnon and T.A. McAllister, 2012. Characterization of rumen bacterial diversity and fermentation parameters in concentrate fed cattle with and without forage. J. Applied Microbiol., 112: 1152-1162. DOI: 10.1111/j.1365-2672.2012.05295.x

Quiroz-Castaeda, R.E. and J.L. Folch-Mallol, 2011. Plant cell wall degrading and remodeling proteins: Current perspectives. Biotechnol. Apl., 28: 205-215.

Shakira, G., I.H. Mirza and A. Latif, 2012. Scope of common DNA based methods for the study of rumen bacterial population. Bang. J. Anim. Sci., 41: 141-146. DOI: 10.3329/bjas.v41i2.14134

Thoetkiattikul, H., W. Mhuantong, T. Laothanachareon, S. Tangphatsornruang and V. Pattarajinda et al., 2013. Comparative analysis of microbial profiles in cow rumen fed with different dietary fiber by tagged 16S rRNA gene pyrosequencing. Curr. Microbiol., 67: 130-137. DOI: 10.1007/s00284-013-0336-3

Van Soest, P.J., J.B. Rbertson and B.A. Lewis, 1991. Method of dietary fiber, neutral detergent fiber and non starch polysaccharides in relation to animal nutrition. J. Dairy Sci., 74: 3583-3597. DOI: 10.3168/jds.S0022-0302(91)78551-2

Weimer, P.J., 2011. End product yields from the extraruminal fermentation of various polysaccharide, protein and nucleic acid components of biofuels feedstocks. Bioresour. Technol., 102: 3254-3259. DOI: 10.1016/j.biortech.2010.11.050

Wilson, D.B., 2011. Microbial diversity of cellulose hydrolysis. Curr. Opin. Microbiol., 14: 259-263. DOI: 10.1016/j.mib.2011.04.004

Yang, L.Y., J. Chen, X.L. Cheng, D.M. Xi and S.L. Yang et al., 2010a. Phylogenetic analysis of $16 \mathrm{~S}$ rRNA gene sequences reveals rumen bacterial diversity in yaks (Bos grunniens). Mol. Biol. Rep. 37: 553-562. DOI: 10.1007/s11033-009-9794-X

Yang, S., S. Ma, J. Chen, H. Mao and Y. He et al., 2010b. Bacterial diversity in the rumen of gayals (Bos frontalis), swamp buffaloes (Bubalus bubalis) and Holstein cow as revealed by cloned 16S rRNA gene sequences. Mol. Biol. Rep., 37: 2063-2073. DOI: $10.1007 / \mathrm{s} 11033-009-9664-6$ 